\title{
THE EVALUATION OF TECHNICAL TRAINING PROGRAM FOR CAREER DEVELOPMENT IN LIMITED COMPANY OF BRANTAS ABIPRAYA JAKARTA
}

\author{
DIDIN HIKMAH PERKASA ${ }^{1}$, SUPARNO EKO WIDODO ${ }^{2}$ \\ State University of jakarta \\ Didinhikmah@gmail.com \\ suparnoekowidodo@unj.ac.id
}

\begin{abstract}
The focus of this research is to ensure that the implementation of the Technical Career Development Program. This research was Review at limited company of Brantas Abipraya Jakarta who use Technical Training as the one of strategy in human capital career development. The research is used evaluation method with CIPP approach. Data were taken using interview guideline, questionnaire observation and document study and analyzed by descriptive method through discussion and triangulation. The component of evaluation aspect (CIPP): Context Evaluation (Context): vision of program mission and program objectives; Input Evaluation: strategy, design, plan and readiness of resources; Process Evaluation (Process): implementation of strategy, design, plan and readiness of resources; Evaluation of Results (Product): Results and Benefits of the program. The findings of the evaluation research, the program's mission, all the strategies, goals and objectives well implemented.
\end{abstract}

Keywords: Program, Evaluation, Technical Training, Career Development, and Implementation

The organization is managed by human resources. There are many problems in management. One of them is how a person has a good career, because everyone who works certainly hope to have a good career. According Riva'i (2015: 207). Job training is one of the company's strategy to develop employee career. Job training in addition to improving the competence of employees, and if done with good planning will improve employee performance and performance. According Kaswan (2013: 2) Job training is part of the human resource management function and must be in line with the vision and mission of the company. Training may also include changing attitudes so that employees can do their work more effectively.

Limited company Brantas Abipraya Jakarta is one of 7 (seven) state-owned enterprises under the auspices of the minister of SOEs. Established on November 12, 1980, is the expansion of the Master Project Development of Brantas River Region. Founded by Ir. Sutami was then Minister of Public Works.

Obtaining the results of the training in accordance with the goals set, the objectives of the program should be formulated based on needs, problems, assets, opportunities, pay attention to legality aspects, then made a plan, implemented, and the results achieved and used as input for the next program. According to Dessler (2011: 293), a systematic method of training process consists of four stages, namely: need analysis step, step instructional design, implement the program step, and the evaluation step. Opinions are almost the same, argued by Anthony, Kacmar and Perrewe (2010: 276) argues that the training process is divided into three stages, namely the assessment stage, training stage and evaluation stage. Based on the expert opinion described above, both begins with the needs assessment activity, and the evaluation stage. Evaluation is useful as a feedback of the whole process. Therefore, evaluation is a very important activity because it helps determine the success of a program. 
Evaluation study conducted by Tulung (2014), entitled Evaluation of Education and Leadership Training Program Level IV On Training Center of Manado, using an evaluation model CIPP (Context, Input, Process, and Product). The results of this study indicate: the program implemented is based on the applicable law; The objectives of the program are suitable for improving the competence of learners; Learners have met the criteria but are still very limited for lecturers and administrative staff; The method used in accordance with the curriculum is the method of coaching; Facilities to meet the standard feasibility; The program has been implemented according to the specified schedule; the overall program evaluation results are showed that, participants, lecturers, and organizers meet the criteria. A holistic understanding of the evaluation is given by Stufflebeam and Shinkfield (2007: 16), which defines evaluation as a systematic process of providing information that can be taken into account to determine the value and benefits of the objectives, design, implementation and impact to help make decision. Based on the two opinions of experts above, it can be formulated that the evaluation as a process of assessing something based on predetermined criteria or goals, then a decision on the object being evaluated. Some the problems are related to the implementation of the training process is not optimal, among others: (a) planning of learning programs incomplete and focus, as well as the implementation is not fully consistent; (B) the instructors' lesson preparation activities are less than optimal; (C) not yet optimal supervision, monitoring and evaluation function as component of quality control; (D) the number and capacity of instructors and training personnel who are still limited; (E) the readiness of infrastructure and facilities such as libraries is still limited; (f) training budget support. Several problems are related to the achievement of training result that have not been optimum such as : (a) unmet requirement of number of experts such as dam, road, bridge and building; And (b) there are still some complaints from participants in career development after training whether their careers will improve.

In order to find out more depth and accurate about the effectiveness level of program implementation, comprehensive program evaluation needs to be done. One program evaluating model most widely known and applied in various fields, namely program evaluation model CIPP (Context, Input, Process, and Product). This model, developed by Stufflebeam, et al., (1967) at Ohio State University. The CIPP model is an evaluation model that views the program as a system. Evaluation model CIPP can be used for summative evaluation (conducted at the end of the program), aimed to obtain information about the quality and value as well as the benefit / significance of a program (summative evaluation: a retrospective use of CIPP information to sum up the program's merit, worth, probity, and significance). Information obtained from the evaluation results useful as consideration for decision makers (decision makers) in decision-making or policy further.

Based on the background of the problem, the purpose of this study is to determine the effectiveness of the program by evaluating: (a) program background, namely: vision, mission and program objectives; (B) program inputs, namely: strategy, design, lesson plans, and readiness of resources; $(\mathrm{C})$ implementation of the program, namely: the implementation of learning programs and activities of learning activities; And (d) program outcomes, namely: results and impacts.

\section{METHOD}

This study is used evaluative approach using CIPP evaluation model according to Stufflebeam, which consists of Context, Input, Process, and Product. The method used is qualitative descriptive. The focus of this research is to evaluated of the implementation of Technical Career Development training program at limited company of Brantas Abipraya Jakarta. The data are collected all primary and secondary data, using interview technique, observation and document study. Data validation is carried out with triangulation of data sources and techniques. Qualitative data analysis is done through data reduction activities, Data presentation, and data verification (Miles and Huberman, 1994: 8-12). The data collected were compared against the evaluation criteria, assessed 
and interpreted using assessment and interpretation guidelines consisting of three categories: (a) $\leq 34 \%$ (less effective); (b) the value of $35-67 \%$ (effective enough); And (c) the value of $\geq 68-100 \%$ (effective). Based on the results / findings of the study carried out the next discussion drawn conclusions and recommendations for the continuation of the program.

\section{DISCUSSION}

The results of the evaluation of the implementation of Technical Career Development training program at Limited Company of Brantas Abipraya Jakarta, as follows:

\section{Background evaluation Program (Context Evaluation)}

a. Vision and Mission Program: The main requirement is the basis of the need for organized technical training courses for career development organization is constantly changing the necessity of having the human capital that is able to compete with competitors. The vision and mission of career development technical training program refers to the vision and mission of the organization. Referring to the vision and mission that the purpose of career development technical training program is to equip or motivate to have the technical expertise to be able to carry out its tasks in the field of construction. This contains the values (values) that will ensure sustainability and long-term success and the mission are realized the vision of the program. The vision and mission formulation has considered the outcomes of the previous program, which will provide direction and as a guide for future planning.

b. Program Objectives: Objective Career Development Technical Training program has been loaded in writing in the formulation of competencies that must be achieved by the participants, namely the mastery of knowledge, skills, attitudes and behavior, ability to work, rights and authority and responsibility as a flight physician. Formulation of program objectives should be based on needs, problems, assets, opportunities (Stufflebeam, 2007: 329). The program has set goals based on the needs, problems, assets, and opportunities and pay attention to the legality, but the formulation of objectives based on the needs of less associated with effectiveness and efficiency.

Overall, the results of the evaluation of the background (context) got a good category, meaning partially or completely foreground program already meets the criteria specified.

\section{Evaluation M forces opened Program (Input Evaluation)}

a. Program Strategy: Strategy is a set of action plans to achieve goals (Anthony, Kacmar, and Perrewe, 2010: 9). The strategy of this program, are: core business skills training appropriate Among other dams, roads, bridges and buildings.

b. Design Program: design training illustrates a procedure or unitary concept with components that have relevance to one another. The design training program followed the rules and procedures set out that the analysis of training needs, with considerations as well as the needs of today's organizations predict future conditions and is expected to continue this program.

c. Lesson Plan: r Plan of learning programs, include: curriculum, lesson plans, phasing, calendar exercise.

d. Readiness Resources: human resources (participants, teachers, managers), teaching materials, and infrastructure (classrooms, support facilities, and training budget.

Overall, the results of the evaluation of the input (input) got a good category, meaning partially or fully enter the program has met the specified criteria.

\section{Evaluation of the Implementation Program (Process Evaluation)}

\section{a. Implementation of Learning Program}


1) K curricula have: The curriculum used in training load training design called the goals to be achieved in the Technical Training Career Development program, the implementation guided by the curriculum / is design used in 2014. M ccording Hamalik (2002: 52), who said that the curriculum contains material which is arranged in the sequence of activities and the scope to cover the areas of teaching, subjects, problems and objects that need to be done.

2) The teaching program: The teaching program aims for all activities carried out by effective teaching and empowering. Therefore, the teaching / syllabi program needs to be guided in teaching activities to be done well. In this training program that s common was appropriate teaching activities and implemented according to plan training programs.

3) Phasing of learning: learning phasing intended to carry out the process / learning activities in a systematic, effective and efficient. Based on interviews with the Senior Manager of Human Capital states that the phasing of training is done at the beginning of the course by taking the pre-test to test the understanding of the participants in these training materials and after the training is completed the posttest to test the participants in capturing the material that has been studied whether there was an increase, so it can be in Implement on the job to be performed.

4) Implementation is workout calendar: Calendar of training should serve as guidance in order to achieve efficiency and effectiveness in the learning process, with the timing of learning activities in a period of a certain period of time. That the implementation calendar Career Development Technical Training program in Limited Company of Brantas Abipraya Jakarta, that has been implemented consistently in accordance with the plans that have been made, and the entire subject matter (type of activity; the number of days and number of hours of lessons) performing well according to the plan are made.

\section{b. Activity of Learning Activities:}

1) Implementation of the trainings activities of the participants is evaluated based on the activities of the participants in the training activities in the classroom, aiming to know the process of conducting the trainings conducted by the participants during the training process. Participants conduct training activities with discipline, motivation, attention, seriousness and responsibility, and supported by facilities and infrastructure / facilities adequate learning. This, according to Mathis and Jackson (2008: 270), who said that efektifitas trainees learning activities, determined by the readiness of the participants themselves in the learning process (learning readiness).

2) Implementation of the teaching activity was evaluated based on the activities of teachers in teaching activities, the implementation of teaching in class. Most teachers always come on time, have reference, systematic delivery, approach, methods and media varied, giving exercises and applicable, problem-solving, to give an example, given the assignment, creating an atmosphere familiarity, be open, and to provide feedback, and can be followed. The components that contribute to determine the effectiveness of the training is learning style (learning style) and the transfer process of learning (learning transfer).

3) Event manager training: The implementation of management training, activities are evaluated based training management activities, aims to understand the process of implementation of the management of technical training programs. The managers carry out training with a good management, backed up to the discipline's, air-motivation to assume joint responsibility for the success of the program, dedicates itself to provide the best service, and displays the attitudes and behaviors that can implemented

4) Budget support exercise: that the implementation of the Career Development Technical Training program using budgetary funds of the Company Budget Work Plan which annually increases. 
Overall, the results of the evaluation of the implementation of the program are assessed in good category, meaning that part or all of the program implementation meets the criteria set.

\section{Evaluation H acyl-Results Program (Products Evaluation)}

Implementation of the program, provides an overview of training outcomes in achieving competency of Career Technical Training program participants: a) Knowledge of Corporate Culture (EPIC) values; B) Natural Resources Project; C) Building Project; D) Bridge Project; E) Road Projects; And f) Dam Project. The average value of knowledge of $>75$ so that aspects of it in accordance with the objectives of the program.

Overall, the evaluation of program results (product) was assessed by both categories, meaning most of the results of programs already meet the criteria set.

\section{Impact Evaluation Program (Outcomes Evaluation) For the Company}

During 2014 and 2015, strengthening is done in all areas, one of which is aggressive marketing strategy. And succeeded in expanding the Company's market segments beyond the core business of the Company's business activities, namely the construction of irrigation (SDA). By strengthening a qualified and highly competitive Human Capital along with the implementation of appropriate marketing strategy, the Company is confident to achieve the Company's mission and vision of becoming a state-owned company or a leading constructor in Indonesia. The company's strategy generated revenues of Rp $3.11 \mathrm{~T}$, jumped sharply from Rp $2.28 \mathrm{~T}$. The surge was accompanied by an increase in operating profit to $\mathrm{Rp} 131.60$ billion, compared to the previous year That position has put the company as a market leader among the other major contractor company, Limited Company of Wika, Limited Company of Hutama Karya and others.

\section{Participants}

Increased competence of human capital can been from three things. First, every new employee is openly recruited through basic and field competency tests. Second, any who will occupy a position promoted through a competency test. Third, every employee who will be prepared to hold the project is given technical training to increase technical competence in the field of work.

\section{CONCLUSION}

Based on the results and discussion, can be summed up as follows: (1) the background of the program (context evaluation): vision, mission and objectives of the program with good category, and meet both criteria; (2) the input program (input evaluation): strategy, design, lesson plans and preparedness program resources with good category, and meet both criteria; (3) the implementation of the program (process evaluation): the implementation of learning programs and learning activities by category of activity is good, and meet both criteria; and (4) The results of the program (products evaluation): results of program performance and impact of programs with both categories, and meet both criteria. the evaluation of Career Development Technical Training program at Limited Company of Brantas Abipraya Jakarta with good category, and meet good criteria. Finally, the program is quite effective and can be continued.

\section{REFERENCES}

Anthony William P., K. Michele Kacmar, and Perrewe Pamela L. (2010). Human Resource Management: A Strategic Approach. United States: Cengage Learning.

Daniel L. Stufflebeam and Anthony J. Shinkfield. (2007). Evaluation Theory, Models, and Applications. San Francisco: Jossey-Bass. 
Gary Dessler. (2011). Human Resource Management, $11^{\text {th }}$ Edition. New Jersey: Pearson Prentice Hall.

Hamalik Oemar. (2010). Human Resources Development: Employment Training Administration Integrated Approach. Jakarta: Earth Aksara.

Jeane Marie Tulung. (2014). "Evaluation of Education and Leadership Training Program Level IV On Religious Training Center Manado" Acta Diurna Journal, Volume III. No.3. Year.

Kaswan. (2013). Training and Development, Human Resources To Improve Performance. Bandung: Alfabeta.

Robert L. Mathis and John H. Jackson. (2008). Human Resource Management, Twelfth Edition.USA: South-Western.

Veithzal Rivai Zainal et al. (2015). Human Resource Management For Companies From Theory Into Practice. Jakarta: Limited Company of Rajagrafindo Persada.

William P. Anthony, K. Michele Kacmar, and Pamela L. Perrewe. (2010). Human Resource Management: A Strategic Approach, Sixth Edition. USA: Cengage Learning. 